suprachiasmatic nucleus of mice. Neurosci Lett 490: 231-236 (2011).

Yang CY, Matsuzaki T, Iijima N, Kajimura N, Ozawa H.: Morphofunctional changes of the astrocyte in rat hippocampus under different corticosteroid conditions. Med Mol Morphol. 45: 206-13 (2012).

Takumi K., Iijima N., Higo H., Ozawa H.: Immunohistochemical analysis of the colocalization of corticotropin-releaseing hormone receptor and glucocorticoid receptor in kisspeptin neurons in the hypothalamus of female rats. Neuroscie Lett. 531: 40-45 (2012)

Takumi K. Iijima N., Iwata K., Higo S., Ozawa H.:
The effects of gonadal steroid manipulation on the expression of Kiss 1 mRNA in rat arcuate nucleus during postnatal development. $J$. Physiol Sci. 62: 453-460 (2012).

Sawai N., Iijima N., Takumi K., Matsuzaki T., Ozawa $\mathrm{H}$ : Immunofluorescent histochemical and ultrastractural studies on the innervation of kisspeptin/ neurokinin B neurons to tuberoinfundibular dopaminergic neurons in the arcuate nucleus. Neurosci Res 74: 10-16 (2012).

Anzai M, Iijima N, Takumi K, Higo S, Sakamoto A, Ozawa H.: Direct and specific effect of sevoflurane anesthesia on rat Per2 expression in the suprachiasmatic nucleus. PLos One in pres

\title{
中枢性オキシトシン受容体の社会行動制御に於ける役割： オキシトシン受容体発現神経回路の生理機能解明を目指して
}

西 森 克 彦 (東北大学農学研究科・分子生物学分野)

E-mail:knishimori@m.tohoku.ac.jp

\section{1. オキシトシン研究の歴史}

本題とは多少ずれるかも知れませんが、ま ず、長いオキシトシンの研究の歴史を最初に 御紹介します。最近は、動物個体間での絆形 成作用や、自閉症への症状改善効果から大き く注目を浴びているオキシトシンですが、そ の研究の歴史は極女て長く、19世紀終わりか ら20世紀初頭にかけて、早くも下垂体抽出 物による分娩促進作用の報告があり ${ }^{1)} 、 1950$ 年代には構造決定や化学合成までもが既に 達成されています2)。フランスのVincent du Vigneaudはオキシトシンとバソプレッシン の二つの下垂体後葉性ホルモンの単離と構造 決定を達成し、1953年にはこれらの化学合成 に成功、人類史上初めてのペプチド・タンパ ク性ホルモン合成の栄誉に輝き、他にインシ ュリンやビオチンの化学構造決定などの業績 を併せて評価されて1955年のノーベル化学 賞を受賞しています。

このように、現代・近代の生物学・内分泌
学研究、神経生理学研究の歴史の中でも極め て長い研究の歴史を持つオキシトシンですが、 その機能については、ごく最近までは分婏や 射乳に関する機能についてよく研究されてき たものの、脳機能や行動生理に関わるオキシ トシンの機能について注目が集まり始めたの は、その長い研究史からみれば、ごく最近の、 精々ここ20数年以降のものです。

\section{2. オキシトシンと受容体の構造、その生理 機能}

オキシトシンは、僅か9アミノ酸から成る 小さなペプチド性ホルモンで近縁のバソプレ ッシンとは2アミノ酸のみ異なり、両者は進 化的にも近いホルモン・遺伝子です。最近の 研究では、オキシトシンはオキシトシン受容 体のにみに作用するわけではなく3）、その逆 に、バソプレッシンも又、バソプレッシン受 容体のみに作用するとは限らないことを示す

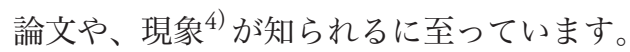


オキシトシンは脳視床下部の室傍核 (Paraventricular nucleus、pvn) と視索上核 (Supraoptic nuleus, son)にある大細胞性ニューロン から合成分泌される事が知られていますが、 その一部は、下垂体後葉へ軸索輸送され、血 流中に分泌されて分娩や射乳などの作用を果 たしている事が知られています。

一方、脳内の様々な神経核にもオキシトシ ン受容体が発現しているらしいことは以前か ら判っていました。しかしこれらの、ニュー ロンに発現するオキシトシン受容体に対して も視床下部のオキシトシンが軸索輸送されて 働きかけ、ニューロン機能を修飾するなどし て様々な生理作用を果たすことが判ってきた のは最近のことですが、今や多数の論文が脳 内のオキシトシン作用を論じています。こ の、オキシトシンの標的ニューロンに発現 する受容体へのオキシトシンの作用の仕方 は、シナプス間で見られる神経伝達物質の作 用のように投射形式なのか、或いは拡散によ る傍分泌的な作用なのか、議論は分かれてい ます。又、脳内の様々な神経核に分布する才 キシトシン受容体に関しても、これに対する 良好な抗体が今に至るまで得られていない事 などから、細胞体内での分布はおろか、脳内 の領域特異的な分布などに関しても詳細は不 明でした。しかし、我々の作成したOXTR-
Venus knockin マウスから得た脳試料の解析 により、社会行動に関連の深い様々な神経核 を中心に脳全体に特異的な分布をしているこ とが明らかとなってきました5)(図1)。オキ シトシン受容体発現ニューロンの分布が判明 するに従い、新たな疑問が想起されてきまし た。脳の様々な神経核に分布するオキシトシ ン受容体は、神経核ごとに、serotonin (5-HT) neuron ${ }^{6)} や$ glutamate neuron、GABA neuron、 dopamin neuronなど、異なる神経伝達物質 作動性のニューロンに発現しており5)、オキ シトシン受容体を発現する神経から成る神経 回路の役割や性質も、領域毎に興奮性であっ たり、抑制性であったりと大きく異なる可能 性が推定されています。

\section{3. 特定の社会行動時に活性化する脳の特定 領域・神経核と、そこで発現するオキシト シン受容体の変動}

各神経核に関して、例えば、視索前野内側 核 (MPOA) は母性行動制御への関わりが著 名であり、同じく外側中隔 (Lateral septal nucleus; LS) や分界条床核 (BnST) なども母性 行動への関与が報告されています ${ }^{7 \sim 9)}$ が、こ れらの領域では強いオキシトシン受容体発現 が見出されました (視索前野、図 2 ; 外側中 隔、図3)。一方、社会的記憶に関係すると

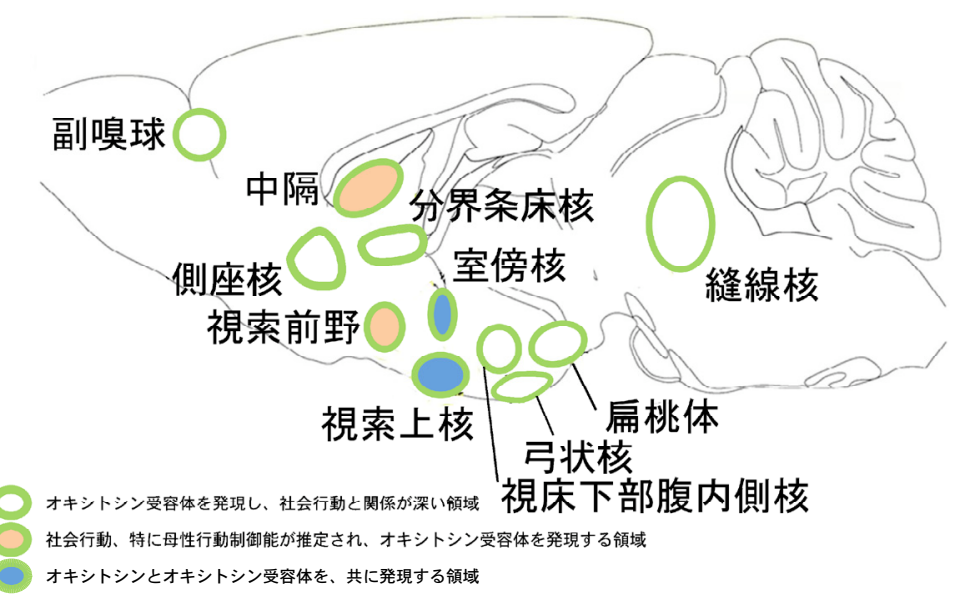

図1 マウス脳の社会行動、母性行動関連領域 (神経核) の中で、オキシトシン、 及びオキシトシン受容体の発現が検出される領域 


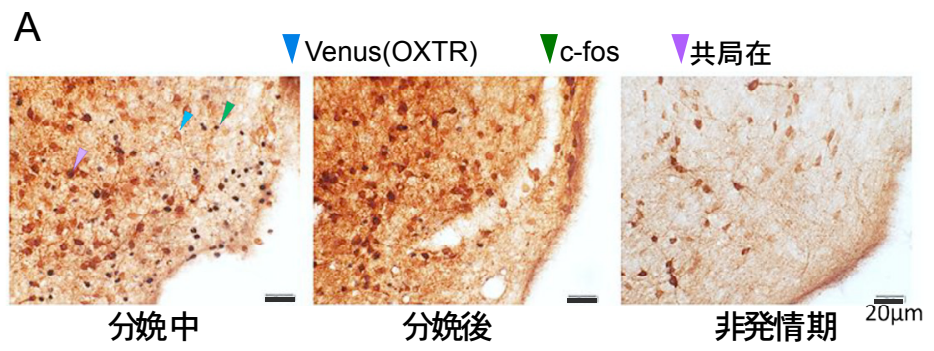

B
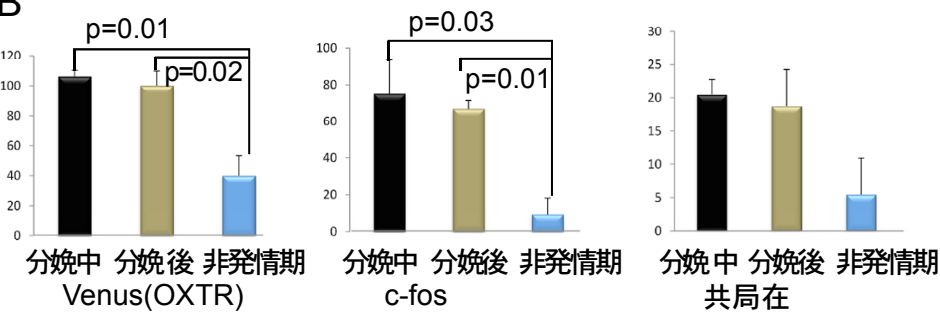

図2 分婏中、分婏後、及び非発情期の雌Oxtr-Venusマウスの視索前野での オキシトシン受容体 (=Venus) と神経活性化を示す c-fosの発現
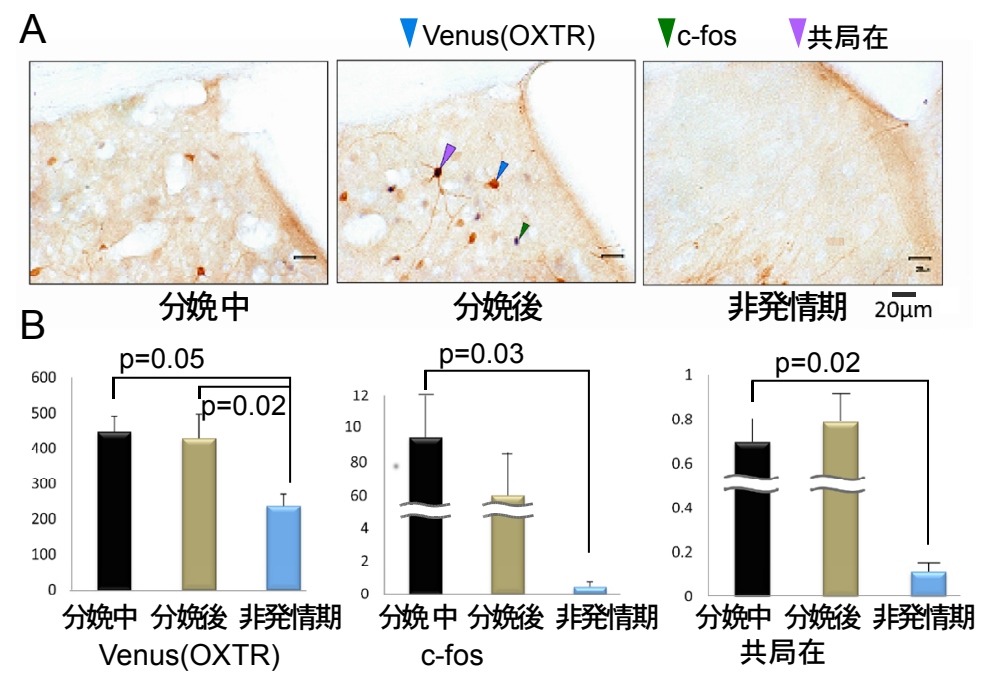

図3 分婏中、分娩後、及び非発情期の雌Oxtr-Venusマウスの外側中隔での オキシトシン受容体 (=Venus) と神経活性化を示す c-fosの発現

される扁桃体内側核 (Medial amygdaloid nucleus; MeA)、雌の場合につがい形成 (pair bonding) に関係するとされる側坐核 (Nacc； ハ夕ネズミの研究 ${ }^{10)}$ などから)、社会行動で はないが摂食行動などと関係するとされる弓 状核 (Arcuate nucleus)、ストレス調節や体温 調節、摂食・飲水などとの強い関わりが知ら れる視床下部 (hypothalamus; 視床下部腹内 側核や視床下部背内側核) などの神経核でも
強いオキシトシン受容体の発現が見出されま した5) (図1)。

しかし、これらの神経核が関わる社会行動 やその他の生理機能に於いてオキシトシン受 容体が果たす役割についての詳細は判ってい ませんでした。我々はこれまでの研究から、 オキシトシン受容体欠損マウスで母性行動の 異常や社会的記憶の低下が見られることを見 出しており ${ }^{11)}$ 、社会行動の中でもこれら母 
性行動と社会的記憶にまずは焦点を絞り、こ れらの社会行動制御に深く関わると考えられ る神経核のニューロンに発現するオキシトシ ン受容体が、これらの社会行動制御に担う役 割を明らかにするために研究を進めました。

\section{4. 社会行動発動時に活性化し、またオキシ トシン受容体発現が上昇する神経核}

4-1. オキシトシン受容体 KOマウスでは母 性行動の低下することが見出されています11) そこでまず母性行動や社会記憶の形成時に神 経が活性化する領域、そしてその際オキシト シン受容体の発現自体も変動するか否か、こ れまでに報告されていた関連神経核の幾つか について調べてみました。

母性行動について関係の深い神経核として は、今までの先行研究から、視索前野 (MPOA) や外側中隔 $(\mathrm{LS})$ 、分界条床核 $(\mathrm{BnST})$ 、そL てオキシトシンニューロンが特異的に局在す る視索上核 $(\mathrm{SON})$ と室傍核 $(\mathrm{PVN})$ などがあ り、それぞれ重要な役割を持つと考えられて きました ${ }^{12)}$ (図1)。我々は、母性行動が誘導 されるという分婏終了時の、視索前野と外側 中隔で、神経活性化因子の c-fosとオキシトシ ン受容体の発現程度 (=Oxtr-Venus マウス脳 でのvenus発現)を調べてみました。その結果、 視索前野、外側中隔共に、コントロールとし て見た非妊娠、未出産マウスの非発情期の脳 の同領域に比べ、分娩中、或いは分娩後には オキシトシン受容体の発現も、又神経活性化 を示す c-fosのレベルも、更にはオキシトシン 受容体発現細胞の活性化を示す、共局在の頻 度も高まることを見出しました(図2、図3)。

4-2. 社会記憶の強弱を定量比較する行動測 定法による、オキシトシン／受容体型欠損マ ウスの解析の結果、社会的記憶に関して、著 者が作成したオキシトシン遺伝子 KO (Oxt/-) マウスを材料に、J N Fergusonらが Habituation-dishabituation testを行った実験では、 Oxt-/ーマウスでの社会記憶の低下が見出され ました ${ }^{13)}$ 。一方、社会記憶を定量するため のやや異なった解析法である Social descrim- ination testにより我々が作成したオキシトシ ン受容体KOマウスの社会行動を、野生型マ ウスのそれと比べた定量評価実験でも、やは りその低下が見出されています11)。そこで、 社会認識時のマウス脳内で起きるc-fosの活 性化やオキシトシン受容体遺伝子の発現につ いて調べてみました。社会認識 (単独飼いし ていた雄マウスケージに卵巣切除マウスを 90秒加える) 後の、c-fos活性が最大になると 言われる90分後に灌流固定して脳試料を調 製、免疫組織染色を行う方法で、社会行動関 連の様々な神経核の免疫染色を行うと、Oxtr-Venus マウス (オキシトシン受容体遺伝子 については hetelozygote) の、特に扁桃体内側 核 (MeA) で、c-fosの活性化が見出され、ま たそれらの多くはオキシトシン受容体発現ニ ユーロンと一致していました (図4)が、これ らの観察結果は、オキシトシン受容体 $\mathrm{KO}$ マ ウス (Oxtr (Venus/Venus)) では見出されませ んでした(data not shown)。

\section{5. 領域特異的オキシトシン受容体遺伝子 KOと、領域特異的オキシトシン受容体遺 伝子のレスキュー}

\section{5-1. 領域特的遺伝子KOと領域特異的遺伝子 レスキューを可能とする系の構築}

その為、オキシトシン受容体遺伝子が LoxPで挟まれたコンデイショナル型 $\mathrm{Oxtr}(\mathrm{fx} /$ $\mathrm{fx})$ マウスを作成し、アデノ随伴ヴィルスを ベースに開発した AAV-Cre vectorの作成によ り、AAV-Creの感染で領域特異的なオキシト シン受容体遺伝子の欠損が誘導できる系を樹 立しました。また、領域特異的にオキシト シン受容体遺伝子の欠損が誘導できる様に、 AAV-OXTR-IRES-Venus vector ${ }^{13)}$ を開発し、 オキシトシン受容体遺伝子欠損マウス $(\mathrm{KO}$ マウス)の特定脳領域にこれを感染させるこ とで、脳領域特異的にオキシトシン受容体遺 伝子を再発現させる系も開発しました。

解析対象領域について、母性行動について は以前から母性行動の制御中枢があると考え られる領域の一つの外側中隔 (LS) を、また 


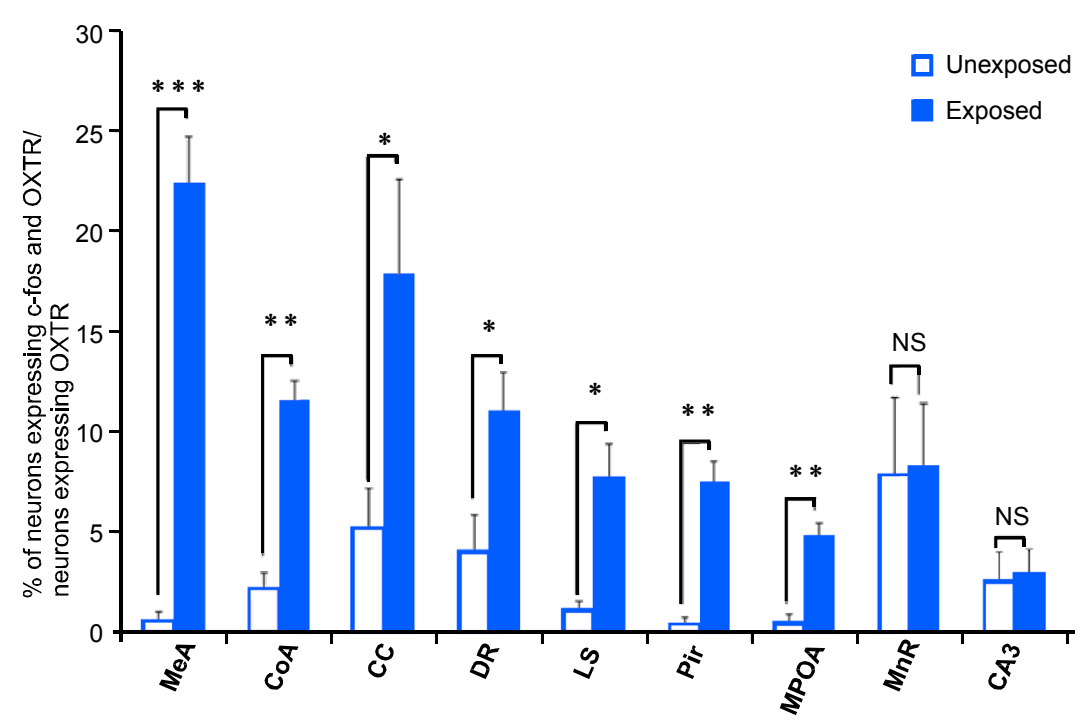

図4 社会認識 (exposed) 90分後に還流固定して調製したOxtr-Venusマウス (ヘテロタイプ) 脳 の社会行動関連領域のオキシトシン受容体発現ニューロン (Venus (+)) でのc-fos 活性化を、 社会認識行動をさせなかった (unexposed) controlマウスの同様処理脳と比較した結果

MeA、扁桃体内側核；CoA、扁桃体皮質核；CC、帯状皮質；DR、背側縫線核；LS、外側中隔； Pir、嗅皮質；MPOA、視索前野；MnR、正中縫線核、CA3、海馬 CA3

社会的記憶に関しては同様に、MeAを選び、 領域特異的遺伝子欠損、領域特異的遺伝子レ スキューの後、それぞれの母性行動や社会記 憶の測定・定量化を行いました。

\section{5-2. 外側中隔でのオキシトシン受容体遺伝} 子欠損と、Oxtr-/-マウス外側中隔への才 キシトシン受容体遺伝子レスキューによる 母性行動

母性行動が障害されるオキシトシン受容体 欠損マウス (Oxtr (-/-)) のLSにAAV-OXTRIRES-Venusを感染させ、 retrieving behavior で母性行動を評価すると、母性行動が回復し ていることが見出されました。一方利型オキ シトシン受容体欠損マウス $(\mathrm{Oxtr}(\mathrm{f} / \mathrm{f} / \mathrm{f}))$ の LSにAAV-Cre vectorを感染させ、LSのみで のオキシトシン受容体欠損状態を誘導しても、 母性行動の障害は殆ど見出されませんでした 14)

\section{5-3. 扁桃体内側核でのオキシトシン受容体} 遺伝子欠損と、Oxtr-/-マウス扁桃体内側 核へのオキシトシン受容体遺伝子レスキュ 一による社会記憶行動

一方、社会記憶が障害されるオキシトシ
ン受容体欠損マウス (Oxtr (-I-)) の MeAに AAV-OXTR-IRES-Venusを感染させた場合 には、社会記憶は回復し、さらにはf $\mathrm{x}$ 型オキ シトシン受容体欠損マウス $(\mathrm{Oxtr}(\mathrm{fx} / \mathrm{fx}))$ に AAV-Cre vectorを感染させて MeA特異的なオ キシトシン受容体欠損状態を誘導しても、脳 を含む体全体のオキシトシン受容体を欠損さ せた、いわゆるコンベンショナル型オキシト シン受容体欠損マウスとほぼ同様に、その社 会的記憶が障害されました ${ }^{15)}$ 。これは、社 会記憶行動に於いては、特にMeAに発現す るオキシトシン受容体の果たす役割が大きい ことを示しており、この MeAに発現するオ キシトシン受容体が、どのタイプ、何を神経 伝達物質とするニューロンで主に発現してい るのか、このニューロンへの入力は、主にど の神経核ニューロン、或いはどの感覚神経か ら来るのか、又どの領域へ走向するのか、才 キシトシン受容体へ受容されたオキシトシン は、このニューロンの働きをどの様に修飾、 活性化 (或いは抑制?) するのか、と新たな 疑問が生まれてきます。こうした疑問に答元 ていくことにより、オキシトシンが中枢で果 
たす役割の詳細とそのメカニズムの詳細が明 らかに成っていくものと考えられます。これ はまた、抗自閉症薬として注目を浴びている オキシトシンの作用メカニズムを、その受容 体側から明らかにしていく研究としても重要 である、と考えています。

\section{6. 終わりに}

今回御紹介した研究は、東北大学農学研究 科・分子生物学分野に在籍した大学院卒業生、 又在籍中の多くの大学院生が築いた様々な遺 伝子改変マウスや解析ツール、dataが基盤と なったものです。その中で、特に佐藤佳亮博 士 (現持田製薬) らが中心となって開発し実 施した実験系を用い、佐藤博士や千葉裕太朗、 長田大知、立石木綿子修士、そして大学院在 籍の浅山瑛美らが行った実験結果を中心に紹 介しました。何ぶん、まだ原著論文として発 表前の段階のもが含まれており、詳しいdata の紹介を割愛せざるを得なかったたことを、 読者の方々にご理解頂ければ幸いです。

又この研究の一部は、文部科学省・科学 研究費補助金課題番号14360046、20380058、 10164609、文部科学省・脳科学研究戦略推 進プログラム課題Fの研究費を受けて行った ものです。

\section{文 献}

1 ) Dale HH, 1906. On some physiological actions of ergot. J Physiol, 4, 163-206.

2 ) Du Vigneaud V, Ressler C, Swan JM, Roberts CW, Katsoyannis PG, Gordon S, $1953 \mathrm{~J}$ Am Chem Soc, 75, 4879-4880.

3 ) Schorscher-Petcu A, Sotocinal S, Ciura S, Dupré A, Ritchie J, Sorge RE, Crawley JN, Hu S-B, Nishimori K, Young LJ, Tribollet E, Quirion R, Mogil JS 2010, Oxytocin-induced analgesia and scratching are mediated by the vasopressin-1A receptor in the mouse. J Neurosci, 30, 8274-84.

4 ) Kawamata M, Mitsui-Saito M, Kimura T, Takayanagi Y, Yanagisawa T, Nishimori K, 2003 Vasopressin-induced contraction of uterus is mediated solely by the oxytocin receptor in mice, but not in humans. Eur J Pharmacol,
472, 229-34

5 ) Yoshida M, Takayanagi Y, Inoue K, Kimura T, Young LJ, Onaka T, Nishimori K 2009 Evidence that oxytocin exerts anxiolytic effects via oxytocin receptor expressed in serotonergic neurons in mice. J Neurosci, 29, 2259-71.

6 ) Tateishi,Y. Sato K, Kasahara Y, Nishimori K Oxytocin Receptors expressed in Glutaminergic neuron in Pallidal raphe nucleus control Body Temperature via thermogenesis" manuscript in preparation.

7 ) Numan M and Stolzenberg DS, 2009 Medial preoptic area interactions with dopamine neural systems in the control of the onset and maintenance of maternal behavior in rats. Front Neuroendocrinol, 30, 46-64.

8 ) D'Anna, K.L., Gammie SC 2009, Activation of corticotropin-releasing factor receptor 2 in lateral septum negatively regulates maternal defense. Behav Neurosci, 123, 356-68.

9 ) Meddle SL, Bishop VR, Gkoumassi E, van Leeuwen FW, Douglas AJ 2007, Dynamic Changes in Oxytocin Receptor Expression and Activation at Parturition in the Rat Brain. Endocrinology, 148, 5095-104.

10) Ross HE, Young LJ, 2009, Oxytocin and the neural mechanisms regulating social cognition and affiliative behavior"Frontiers in Neuroendocrinology. 30, 534-547 (2009).

11) Takayanagi Y, Yoshida M, Bielsky IF, Ross HE, Kawamata M, Onaka T, Yanagisawa T, Kimura T, Matzuk MM, Young LJ, Nishimori K 2005, Pervasive social deficits, but normal parturition, in oxytocin receptor-deficient mice. Proc Natl Acad Sci USA, 102, 16096101.

12) Leckman JF, Herman AE, 2002, Maternal Behavior and Developmental Psychopathology. Biological Psychiatry, 51, 27-43.

13) Sato K, Osada D, Asayama E, Kasahara $Y$, Yamashita A, Hidema S, Mizukami H, Ozawa K, Nishimori K, 2013, Core function of oxytocin receptor-expressing neurons in the lateral septal nucleus for regulation of maternal behavior. (manuscript in submission)

14) Sato $K$, Chiba $Y$, Hidema S, Mizukami $H$, Ozawa K, Nishimori K, 2013, Oxytocin receptor expressed in neuron at the MeA is suspected to be one of major players controlling social memory. (manuscript in preparation)

15) Ferguson JN, Young LJ, Hearn EF, Matzuk MM, Insel TR, Winslowet JT, 2000, Social 
amnesia in mice lacking the oxytocin gene. Nat Genet, 25, 284-8.

16) Sato,K. Date S, Aoyagi Y, Kasahara Y, Nawa A, Mizukami H, Hidema S, Ozawa K, Nishimori K, 2009, Generation of adeno-associated virus vector enabling functional expression of oxytocin receptor and fluorescence marker genes using the human eIF4G internal ribosome entry site element. Biosci Biotechnol Biochem, 73, 2145-8.

\section{ヒト生殖の臨床現場から 〜進化の遺産と現代社会の制約〜（子宮内膜症を題材にして）}

和 泉 俊一郎 (東海大・医学部専門診療学系産婦人科)

E-mail: s-izumi@is.icc.u-tokai.ac.jp

\section{1.はじめに}

本稿は福井大学主催で行われた第37回日 本比較内分泌学会大会において大会実行委員 会主催シンポジウムとして行われた「生殖と 行動—細胞内シグナルから脳高次機能研究ま での最前線一」のシンポジウムで和泉が担当 した講演「ヒト生殖の臨床現場から〜進化の 遺産と現代社会の制約〜 (子宮内膜症を題材 にして)」を論文形式にまとめたものである。 比較内分泌学会は、ある現象について、異 なる種をつなぐ共通点と種を隔てる相違点を 我々に明示してくれる点で、内分泌学を研究 するものにとっては非常に興味深い分野であ る。しかし、多彩な動物種に跨がる研究や多 彩なホルモン分子種に跨がる研究を一人の研 究者がすることは難しく、いかにこれを総合 的に提示していくかという点は、困難な問題 かもしれない。一方、ヒトの内分泌を扱う我々 にとっては、in vivoのデータはほとんど動物 実験からのものであり、ヒトという種におい て直接in vivoの実験を行うことは不可能に近 い。そのため我々は動物データからヒトの内 分泌動態を解釈し、そのアナロジーで考えて いる事が多い。しかし、その反面、時として このために大きな曲解に陥ってしまうかもし れない。そのことは医師として常に自戒して おかなければならないと考えている。本稿に おいては、ヒトの生殖に関する本来の行動と、
現代となったことにより問題が浮き彫りとな ったことについて、子宮内膜症を題材として 話題を提供する。

\section{2. 比較内分泌学とヒトの生殖 ヒトの生殖の特徵}

ヒトの生殖を他の動物種と比べた場合、特 徵的なものが幾つかある。特に図1に示した ように、月経という現象は必ずしも他の動物 種において見られるものではなく、進化の過 程でその月経という現象を獲得して進化して きた種がヒトである1)。

この月経に関する議論はここではこれ以上 触れないが、その後の妊娠というものを考え たとき、ヒトは基本的には単胎で子宮内に子 供を育て分婏するというのが特徴である。他 の種、例えば魚類は沢山生み成長までの間に 淘汰されることを見込んだ多産である。種に より生き残りをかけて、種の保存のための戦 略を種々にとつている。さて、我々ヒトの場 合は生まれても立って歩くことはできず、八 イハイして移動できるようになるまで約 8 ケ 月かかる。生まれてすぐ立ち上がる他の哺乳 動物たちと比べて遙かに未熟な状態で分娩す ることが分かる。この理由の一つとして、他 の哺乳動物は4足歩行で重力に抗する骨格に なっているため骨盤が円筒形の単純な構造を している。一方、ヒトは森林を出て草原・ 